DOI: $10.11649 / a .1974$

Article No.: 1974

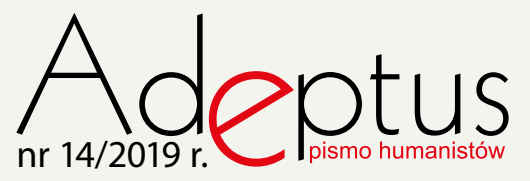

Absolwent filologii czeskiej na Uniwersytecie Jagiellońskim w Krakowie. Do jego zainteresowań naukowych należą fenomeny kulturowe Europy Środkowej, problematyka pogranicza i współczesna ewolucja języka. Tematem omawianym w artykule zajmował się w swojej pracy magisterskiej.

ORCID: https://orcid.org/0000-0003-2113-8669

e-mail: kam.czainski@o2.pl

Kamil Czaiński

\title{
Ponašymu - mieszany kod językowy czeskiego Śląska Cieszyńskiego
}

\section{Wprowadzenie. Śląsk Cieszyński i jego język do roku 1920}

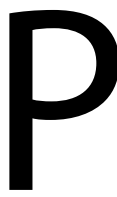

ojęcie „Śląsk Cieszyński” ściśle wiąże się z pierwotnie piastowskim, a następnie habsburskim Księstwem Cieszyńskim, które na kartach historii Europy Środkowej pojawia się w roku 1290. W tym czasie formalnie samodzielne księstwa śląskie znajdowały się już wyraźnie w orbicie wpływów czeskich. Zostało to przypieczętowane ich włączeniem do Korony Czeskiej w pierwszej połowie XIV wieku, a w wypadku Księstwa Cieszyńskiego w roku 1327, gdy książę Kazimierz I złożył hołd lenny królowi Janowi Luksemburskiemu (Bakala, 1992, ss. 20-21). Od strony etnicznej księstwo zamieszkiwała w większości ludność słowiańska - z wyjątkiem wschodnich peryferii miasta Bielska (niem. Bielitz) tworzących obszar osadnictwa niemieckiego, określany później jako bielsko-bialska wyspa językowa (Bielitz-Bialaer Sprachinsel). Linia rzeki Łucyny, płynącej przez zachodnią część regionu, tworzyła izoglosę występowania prasłowiańskiego $g$ (na wschód od niej) i jego przejścia w h (na zachód od niej), stopnia denazalizacji samogłosek nosowych (zachodnie ćeški i wschodnie ćynški, zachodnie łuka i wschodnie łunka) oraz odmiennego rozwoju grup TorT, TolT - krava na zachodzie i krova na wschodzie, młady na zachodzie i młody na wschodzie a co za tym idzie oddzielała gwary śląskie o przeważających cechach lechickich (pokrywające około 80\% obszaru Śląska Cieszyńskiego z Cieszynem włącznie) od gwar laskich czy też śląsko-morawskich, o przeważających cechach czesko-słowackich (Hannan, 1996, s. 125). 
llekroć w niniejszej pracy jest mowa o "dialekcie”, "języku ludowym” czy "miejscowym”, ma się przez to na myśli owe lechickie gwary śląskie. Dla najbardziej nas interesującej części regionu, jaką jest współczesny pas pogranicza czesko-polskiego, wyróżnia się wśród nich następnie właściwą gwarę cieszyńską (środkową), gwarę jabłonkowską (góralską), gwarę frysztacką/karwińską i bliską centralnemu Śląskowi gwarę bogumińską (północną) (Hannan, 1996, s. 120).

W XV wieku, po okresie wyłączności łaciny i języka niemieckiego, jako język literacki, urzędowy i kancelaryjny w Księstwie Cieszyńskim zaczął być stosowany język czeski. Najstarszy pisany po czesku dokument pochodzi z roku 1434, a pod koniec tego stulecia czeszczyzna zaczyna dominować we wszystkich śląskocieszyńskich miastach: nawet etnicznie czysto niemieckie Bielsko w latach 1475-1560 prowadziło zapisy urzędowe po czesku (Hannan, 1996, s. 148). Ogłoszone 24 czerwca 1573 roku przez księcia Wacława III Adama Zemské zřizení knížecství těšínského (Ustrój ziemski księstwa cieszyńskiego) ustanawiało język czeski językiem urzędowym księstwa. Czytamy tam m.in. w artykule 20:

Gdyby zaś kto jakie roszczenia, pisma czy świadectwa udowadniać chciał przed sądem w innym, a nie czeskim języku, powinien to sobie dać przez zaufane osoby na czeski przetłumaczyć i na czas przed rozprawą wypisać, i po czesku roszczenia swoje powinien przedłożyć, równie dobrze cudzoziemiec, co krajan (cyt. za: Šefčík, 2001, s. 64)'.

Z kolei w artykule 18 odnajdujemy stwierdzenie: „Przed sądem po czesku albo w do tego języka podobnej mowie ma być mówione przez obcych i swoich, i tak też spory prowadzone być mają"² (Šefčík, 2001, s. 63). Warto zwrócić uwagę na określenie „tomu jazyku podobná řeč" (pol. „do tego języka podobna mowa”), które wyraźnie wskazuje na świadomość XVI-wiecznego ustawodawcy, że istnieje zasadniczy rozdźwięk między językiem czeskim a językiem realnie używanym przez mieszkańców księstwa, jakim był ludowy dialekt śląski. Analizując nowożytne piśmiennictwo czeskie na Śląsku Cieszyńskim odnajdujemy w nim wiele "błędów" i nietypowych dla czeszczyzny form, pokazujących, że język ten był dla śląskich autorów mimo wszystko kodem obcym, a dialekt miejscowy rozbrzmiewał pośród wszystkich warstw społecznych. Tak oto Alois Knop, autor monografii Spisovná čeština ve Slezsku v 16. století wymienia takie często występujące zjawiska, jak:

\footnotetext{
1 "Pak-liby kdo jaké spravedlnosti, listy aneb svědectví prokazovati chtěl před soudem jiným a ne českým jazykem, ten to sobě na česko hodnověrným osobám přeložiti a časně před stáním pilně vypsati dáti má a českým jazykem spravedlnosti své předložiti má, tak dobře cizozemec, jako obyvatel." Wszystkie tłumaczenia, jeśli nie zaznaczono inaczej, autora artykułu.

2 "Před soudem česky aneb tomu jazyku podobnou řečí a ne jináče ode všech cizích i domácích mluveno a pře vedeny býti majï".
} 
- formy bez czeskiego przegłosu typu baran, od pola, rzetaz

- u zamiast au (smluva, kupyl)

- o zamiast ů w celowniku liczby mnogiej (domom, dietom)

- sylabiczne $r$ i / w sąsiedztwie samogłosek (hernecz, welna)

- zaznaczanie wymowy dź/ć zamiast $d^{\prime} / t^{\prime}$ (dziedzinie, do smerczy) i zmiękczenia innych spółgłosek (do Strumienia, przedkowie)

- rozłożone nosówki (trombe, beczkem)

- samogłoski pochylone ( $/ k l o r z, z a h u n$ zeli)

- konsekwentny zapis -uw w dopełniaczu liczby mnogiej (organuw, dwu pyecuw)

- wahania w zapisie długości - nadmiernie oznaczane w sylabach akcentowanych paroksytonicznie (pochwálu, dalékych, zwěltowátel), gdzie indziej zaś brakujące (przikladu, rozgimáni, žádam) (Knop, 1965, ss. 23-47).

W wieku XVIII na powrót wzrosło znaczenie języka niemieckiego, zwłaszcza po reformie szkolnej Marii Teresy z roku 1774, aczkolwiek w szkołach ludowych, kościołach czy urzędach język czeski, zwany tu również bardzo często „morawskim” (zob. Hannan, 1996, s. 133), był powszechnie obecny jeszcze w połowie XIX wieku. W praktyce o ile podręczniki czy śpiewniki drukowane na Morawach były rzeczywiście czeskojęzyczne, to ludność miejscowa często używała również w piśmie i w kontaktach oficjalnych swoistej czesko-śląskiej mieszanki językowej. Przykładem może być poniższe pokwitowanie sprzedaży gruntów wydane w podcieszyńskim Puńcowie (czes. Puncov, niem. Punzau) w roku 1837:

\section{Quittung}

na 16 fl 53 kr C.M., prawim Szesnaście Ryńskich 53 Xr strzebemich piniendzy, które Jerzy Beness, Przigimatel Gruntu pod Nr. 65 w Puńcowie podug swoigo kupu Act 2 intab. 30 Octobra 1812, do Sztalmachowey Masy należonce piniondze, mie Niże podpisaney, iak moy erbowni dział, do moich własnych rąk, dobrze odliczone, w przitomności trzech godnowiemych świadków, oddal. Na co dozwoluie żeby ty wyzmienione piniondze z gruntowey Ksiegi wymazane były.

W Puńcowie dnia 20. Decembra 837.

+++ Ewa rodzono Benesz, wydano Kordon, Odbieratelkinia

Jan Sniegon, Podpisowatel a Świadek

Andryd Glaycar Świadek

Paweł Kayzar Świadek (Poloczkowa, 2003, s. 41) 
Od XVII wieku pojawia się na Śląsku Cieszyńskim w użyciu również język polski w dokumentach urzędowych w pojedynczych zaledwie przypadkach, częściej w książkach "dla ludu" o tematyce religijnej czy poradnikowej. Za pierwszą polską książkę uznaje się Wierność Bogu y cesarzowi czasu powietrza Morowego, należq̨ca á pokazána przez Jána Muthmána sługę Ewanieley przi kościele Jezusowym przed Cieszynem wydaną w 1716 roku (Raclavská, 1998, s. 37). Podobnie jak czeszczyzna, również polszczyzna Śląska Cieszyńskiego wykazywała wyraźne cechy regionalne, m.in. denazalizację samogłosek nosowych. Na przykład we wstępie do wydanej w 1761 roku książki Prawdziwa Jedźina do Nieba z Pisma Swientego dokazana Droga autorstwa grupy księży katolickich z Jabłonkowa, Cieszyna i Raciborza czytamy:

Łaskawy Czytelniku! Oto ci sie podaje Kśionszka nowo, która jakkolwiek stare Rzeczy w sobie zawiera, przece noworzeczona, że twojemu Jenzykowi a mowie w Druku przysposobiona popierwsze na Światło wychodzy, aby tym milsza, y każdemu przyjemniejsza była czym snadniejsza bendzie do wyrozumienia (cyt. za: Raclavská, 1998, s. 39).

W tym samym czasie zaczynają też powstawać tzw. zapiśniki, czyli pamiętniki chłopskie, będące cennym przykładem twórczości w języku ludowym, oczywiście również niepozbawionym wyniesionych z dostępnej w regionie literatury wpływów czeskich i polskich, przez co stanowią też przykład pewnej mieszanki językowej. Pierwszym ich twórcą - tzw. piśmiorzem - był Jakub Galacz z Żukowa Dolnego, autor utworu Pisniczka pobożna ewangelitska slożena w ten czas 1709 kdyż tak hrabie Sytzendorffu komisarz cysarzski przi meste Tessyne kostel a sskolu ewangelikum wystawiti naweczne czasy gmenem cysarze placz pokazal a oddal oraz kroniki z lat 1698-1717 (Raclavská, 1998, s. 45). Najbardziej znanym i najczęściej w tym kontekście przytaczanym autorem jest natomiast furman z Małej Cisownicy Jura Gajdzica, autor kroniki Nieco z kroniki Cieszęśki obejmującej lata 1211-1823 oraz pamiętnika Dlo pamięci rodu ludzkiego (1840), w którym odnaleźć można zarówno bohemizmy leksykalne, jak i ślady lokalnej gwarowej fonetyki i form gramatycznych. Czytamy w nim na przykład:

Roku 1812 przed Gody Francuz prziszeł na Mozgola do bitki, ale sie Francuzowi źle podarziło, Pon Bóg mu tam bardzo wybił, trefiła zima wielko i mróz i zmorz tam, że sie go mało wróciło i musioł sie wrócić chned w poście z Galicje. Potem sie zaś woyna szczęła, Cysorz z Francuzem. I nasze cysarskie woysko też sie wrociło z Polski i tu były tak wielki marsze, że yuż nie szło ku wytrwaniu a trwały od Apryla aż do Czerwienca, że niekiedy było 8 koni u yednego Pasieczana (gazdy z Małej Cisownicy), tego roku 1813 
też wtedy wtych marszach szli Francuzi, Harwoci i wszelijaki zbierwy a ściągali sie ku Pradze i tam sie potem zaczęła woyna (cyt. za: Spyra, 2006, s. 38).

Wiosna Ludów przyniosła wydarzenia, które zasadniczo wpłynęły na dalszy rozwój sytuacji socjolingwistycznej na Śląsku Cieszyńskim. W 1847 roku uczeń cieszyńskiego gimnazjum ewangelickiego Andrzej Cinciała utworzył przy swej szkole towarzystwo uczących się języka polskiego. Rok później, w maju 1848, założył razem ze szkolnym kolegą Pawłem Stalmachem i prawnikiem Ludwikiem Kluckim „Tygodnik Cieszyński" - pierwsze polskojęzyczne i propolsko nastawione czasopismo $w$ regionie. $W$ tym samym roku jesienią powstała Czytelnia Polska (Kadłubiec, 1997, s. 21). Polskiemu ruchowi udało się w krótkim czasie osiągnąć wprowadzenie języka polskiego do kościołów katolickich i ewangelickich, a także polskojęzycznych podręczników do szkół ludowych w prawie całym Księstwie - z wyjątkiem dekanatu frydeckiego, a po protestach kilku miejscowości także dekanatu frysztackiego (Bogus, 2012, s. 339). W kolejnych latach polszczyzna zyskiwała coraz silniejszą pozycję na Śląsku Cieszyńskim. Decydujący okazał się rok 1867, gdy nowa konstytucja, przekształcająca Cesarstwo Austriackie w monarchię austro-węgierską, zagwarantowała „równouprawnienie wszystkich istniejących w kraju języków w szkołach, urzędach i życiu publicznym". Niemniej państwo austro-węgierskie przewidywało istnienie wyłącznie dziewięciu landesübliche Sprachen (pol. języków zwyczajowych w krajach), tj. niemieckiego, węgierskiego, "czesko-morawsko-słowackiego”, polskiego, „rusińskiego”, rumuńskiego, serbsko-chorwackiego, słoweńskiego i włoskiego, dlatego większość obszaru Śląska Cieszyńskiego - z wyjątkiem bielsko-bialskiej wyspy językowej oraz używającego gwar laskich zachodniego pasa od Frydka do Śląskiej Ostrawy - uznana została za „polskojęzyczną” (Wandruszka \& Urbanitsch, 2003, s. 44). Polscy narodowcy nazywali ten obszar „polskim narodowym stanem posiadania", który wzmacniany był przez napływ polskich robotników z Galicji, zwłaszcza do Zagłębia Ostrawsko-Karwińskiego (Kadłubiec, 1997, s. 26).

W drugiej połowie XIX i na początku XX wieku na ziemi cieszyńskiej współwystępują trzy podstawowe kody językowe. Pierwszy to język niemiecki, jako prestiżowy język państwowy używany przez wszystkie narodowości, którego znajomość jest konieczna do osiągnięcia awansu społecznego. Drugi - język polski (w powiatach bielskim, cieszyńskim i frysztackim) lub czeski (w powiecie frydeckim) jako język literacki dla ludności miejscowej - język prasy,

\footnotetext{
${ }^{3}$ Artykuł 19 konstytucji, niem. „Die Gleichberechtigung aller landesüblichen Sprachen in Schule, Amt und öffentlichem Leben wird vom Staate anerkannt" (Staatsgrundgesetz vom 21. December 1867, über die allgemeinen Rechte der Staatsbürger für die im Reichsrathe vertretenen Königreiche und Länder, b.d.; wersja polska za: Kasza, 2009).
} 
Kościoła, władz lokalnych, wreszcie szkolnictwa podstawowego i częściowo średniego. Trzeci to wreszcie lokalny język śląski, pozostający podstawowym kodem komunikacyjnym, ale ograniczonym do sfery prywatnej, a jeśli zapisywany, to w tekstach rozrywkowych czy folklorystycznych, ewentualnie w rozmaitych odezwach do ludu w kontekście ówczesnej walki politycznej (Hannan, 1996, s. 152). Nie podjęto na szerszą skalę działań kodyfikacyjnych i starań o usamodzielnienie się śląszczyzny - czy to w obrębie samego Śląska Austriackiego, czy to wspólnie z pruskimi Ślązakami - jako pełnowartościowego języka literackiego. W 1910 roku Józef Kożdoń - lider Śląskiej Partii Ludowej reprezentującej tych Cieszyniaków, którzy utożsamiali się z pojęciem narodowości śląskiej i sprzeciwiali się rosnącym wpływom polskiego ruchu narodowego i jego próbom polonizacji regionu - założył Komitet dla Utrzymania Czystości Dialektu Śląskiego, ale jego działalność była efemeryczna, a sam tygodnik „Ślązak", organ tejże partii, wydawany był zasadniczo po polsku, a w języku miejscowym publikowano jedynie krótkie teksty, takie jak dowcipy, wierszyki, ludowe gawędy, krótkie felietony i manifesty (Hannan, 1996, s. 158).

Język ludowy podlegał w tym okresie silnym wpływom z jednej strony niemieckim z tych czasów pochodzi większość charakterystycznych dla śląszczyzny germanizmów, których część (np. ganc, richtik, verk) zachowuje się do dziś w świadomości Cieszyniaków - z drugiej zaś literackiej polszczyzny czy czeszczyzny wyniesionej ze szkoły i prasy. Teksty śląskie $z$ tego okresu pełne są niekonsekwencji w zapisie nawet tych samych wyrazów w jednym zdaniu, losowo pojawiają się formy przejęte z języków literackich (np. nosówki $q$ i ę) obok prób czysto fonetycznego oddania wymowy (np. zapis ubezdźwięcznień).

Przykładem mogą być następujące dwie odezwy polityczne z lat 1920-1921, w których poprzez użycie dialektu chciano przemówić do dusz lokalnej ludności:

Ślonzocy!

Jeszcze przet 80 rokami bronili sie naszy przotkowie przed spolszczynim. Prawili hernie że som Morawcy! We szkołach czytali z morawskich ksionżek, w kościele rzykali i śpiwali z morawskich kancynołuw, doma rzondzili po naszymu.

Podziwejcie sie na gory a najdziecie tam jeszcze dość morawskich ksionżek. Kandy sie tam wziyny? Jeszcze przed niedownym czytali w nich waszy ojcowie, starzicy, matki i starzynki. Aż do dzisio mają te ksionżki w zocy!

Prziszoł ksiąc - polak, rechtor musieli uczyć po polsku, aby nie stracił zarobku w kościele. Rakuski urzyndy pomogały polszczyć. Ślonski lud oprzył sie na moc miejscach polszczynie. Ślonscy Morawcy w mocka dziedzinach bronili sie a jejich postympowani musi być i dzisiok jeszcze ślonzkimu ludowi wzorem. [...] 
Děšintero přikozani dla Šlonzoka před glosovanim:

1. Věř sobie samymu, polskim agitatorum něvěř!

2. Paměntej ynym svojigo vlasnigo dobra!

3. Paměntej přislosti svoji a svojich děci!

4. Šanuj ojca svojigo i matki svoji i přodkuv svojich, kieři od věkuv byli v paňstvě českim!

5. Nězabiješ sebě i svojich potomkuv glosovanim dla paňstva polskigo!

6. Nědej sě svist' přivandrovalcami z Galicyje, abys zapřil svojum krev!

7. Nědej sobě ukrast' svojum bogatum zimiu šlonskum Polokami!

8. Nědej nic na falešne sviadectva a plotki polski!

9. Něžič sobie dobrobytu polskigo, bo go nima!

10. Glosuj s pelnym přesvědčinim dla republiki českoslovacki!

(cyt za: Gawrecki, 2017, s. 143)

Podobną mieszankę form śląskich, polskich i czeskich, a czasem nawet równoległe wersje tego samego wyrazu (np. „moja złata” i „moja złoto”), przedstawia list prywatny napisany w II połowie XIX wieku przez mieszkańca Istebnej:

Niech bedzie pohwalony Jezus Krystus moja złata Marenko ja če pozdrawujem na niezliczene razy a cesziłoby mie to gdyby če tyh moih paru słow przi dobrem a stałem zdrawiu wynatreficz mohło ja sem hwała Panu Bogu zdrawy a powodzeni moje jak w tej smutnej Ostrawie tu kartku Cosz mi pisała toh dostał i tak czi zaniu dziękujem bardzo pieknie piszeš mi až przijadem na odpust ale moja złoto Marenko nimožem rad byh bardzo przijehacz aleh dostał kartku ku wojsku na dewatnastego usz mušiu bycz w czeszinie na 13 dni tak mi to miła Marenko niepasuje jechacz dodom teras a zaš potem zatydzieň bardzo mie To mierži že nimožem jehacz usz še tam musziš sama za ten czas czeszicz bo ja gdyžby nie to to byh przijel [...] (Hannan, 1996, s. 153).

\section{Ponašymu - współczesny język mieszany czeskiej części regionu}

Po I wojnie światowej i upadku monarchii austro-węgierskiej Śląsk Cieszyński stał się przedmiotem sporu terytorialnego pomiędzy nowo powstałymi państwami: polskim i czechosłowackim. W dniu 28 lipca 1920 roku Rada Ambasadorów zadecydowała o podziale regionu. Polska otrzymała Bielsko z całą niemiecką wyspą językową, dolinę Wisły ze Skoczowem, 
Ustroniem i Strumieniem oraz prawobrzeżną część Cieszyna, Czechosłowacja całe przemysłowe Zagłębie Ostrawsko-Karwińskie, Frydek, Trzyniec, okolice Jabłonkowa (bez Istebnej, Jaworzynki i Koniakowa) oraz lewobrzeżny Cieszyn. Dalszy rozwój językowy w polskiej części regionu związany jest z postępującą asymilacją w kierunku języka polskiego, który na całym obszarze jest od 1920 roku, z wyjątkiem czasów II wojny światowej, jedynym językiem urzędowym, Jednocześnie głównym kierunkiem obustronnych migracji ludności pozostaje polski interior.

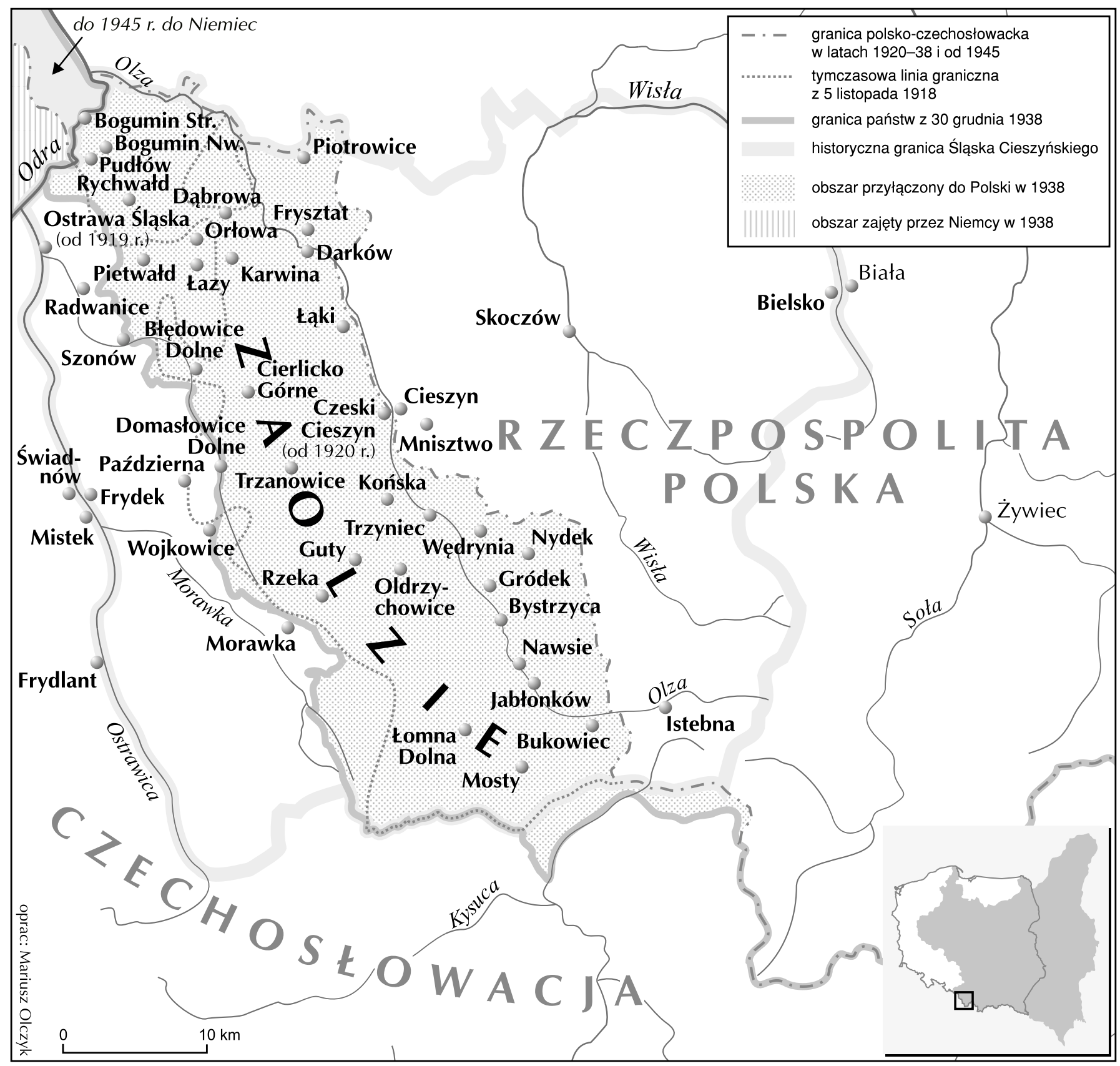

Przesunięcia granicy polsko-czechosłowackiej na Śląsku Cieszyńskim w latach 1918-1945 (mapa za: Gąsior, 2008, s. 3) 
Sytuacja w części czechosłowackiej była o wiele bardziej złożona za sprawą większego oddalenia na płaszczyźnie fonologicznej i morfologicznej powszechnie używanego języka ludowego (śląskiego dialektu cieszyńskiego) od standardowej czeszczyzny z jednej strony, z drugiej zaś w związku z wykształceniem się w poprzednich dekadach silnej polskiej mniejszości narodowej, a w konsekwencji obecności polskiego szkolnictwa podstawowego i średniego, polskich organizacji kulturalnych, możliwości używania języka polskiego w kontaktach urzędowych itp. Te dwa czynniki wyraźnie spowolniły procesy asymilacyjne w kierunku czeszczyzny. Głównym źródłem nowej fali ludności napływowej po II wojnie światowej nie były zaś tereny czeskojęzyczne, ale Słowacja.

W konsekwencji doszło w ciągu XX wieku do wykształcenia się w pasie przygranicznym, w polskiej tradycji nieprecyzyjnie nazywanym „Zaolziem” (zob. Gąsior, 2008, s. 2), specyficznego kodu językowego, który łączył elementy tradycyjnego dialektu cieszyńskiego ze standardowym językiem czeskim i był wzbogacany o elementy zapożyczone z języka polskiego i słowackiego. Lekt ten określany jest przez samych użytkowników najczęściej jako ponašymu. Określenie to - jakkolwiek popularne w różnych odmianach w różnych zakątkach Europy Środkowo-Wschodniej, np. dolnołużyckie ponaschemu czy podlaska svoja mova - przyjęło się również wśród wielu badaczek i badaczy tematu (Bogoczová \& Bortliczek, 2017, s. 21).

Mamy tu do czynienia z czymś w rodzaju języka hybrydowego czy interjęzyka, zjawiskiem podobnym np. do surżyka, czyli chaotycznego mieszania elementów języka ukraińskiego i rosyjskiego przez szerokie warstwy mieszkańców Ukrainy (zob. Fałowski, 2011, ss. 140-141). Użytkownicy ponašymu sięgają w dość losowy sposób po środki językowe z kodu, do którego mają najłatwiejszy dostęp. Nie jest to tylko nakładanie czeskiej leksyki na śląski system fonologiczny i morfologiczny, paleta możliwości jest o wiele bogatsza. Różne formy tego samego wyrazu czy paradygmatu potrafią współwystępować w jednej wypowiedzi jednego rozmówcy. Wyrazy o podobnej formie obecne w różnych językach, na których zbudowane jest ponašymu (śląski, czeski, polski, słowacki), ale z odmiennym znaczeniem, potrafią być używane równolegle w różnych spośród tych znaczeń (řykać jako modlić się i jako mówić, čuć jako czuć i jako słyszeć). Jedno pojęcia miewa często szereg synonimów (kyrchuv - cmyntoř - hřbitov - cintorin, cug - poćung vlak, mjyškać - bydleć - byvać) zapożyczonych z różnych języków występujących w okolicy.

Poniżej znajdują się fragmenty dwóch rozmów nagranych w trakcie badań terenowych prowadzonych przeze mnie w sierpniu 2018 roku. Litera ů w transkrypcie oznacza „pochylone o", charakterystyczną dla śląszczyzny głoskę pośrednią między o i $u$, za pomocą ô oznaczono labializację głoski o, pozostałe litery należy czytać zgodnie z czeskimi (š, ž, č, ň, ř, h, ch, d', t', í, ú) 
i polskimi (ś, ź, ć, ł, i, y, ie) zasadami wymowy. Nie zostały oznaczone ubezdźwięcznienia i udźwięcznienia wewnątrz- i międzywyrazowe.

W pierwszej z przytaczanych rozmów uczestniczyła grupa dwudziestokilkulatków ze wsi Herczawa w południowej części regionu przy czesko-słowacko-polskim trójstyku:

- To je Chytry kviz, a vidźiš jacy chytři som, no...

- Ale nejgorśi je ta typovačka, ňi? Michaela Jílkova, vole, a kolik ona natočila dilú toho Mate slovo, a jo pravim že, kurva, jo se kejśi s učitelkům bavił, ešče na zakladce to było, tak možna v ôsmej třidźe, ňi? A tož, kurva, to je každy mjeśůnc, sům śtyry dilly, ty vole, krat osum, tak jech vyrachovoł třista osumdesat śtyry dilily.

- Ale ty žeś to až pozd'e povjedźoł!

- No, jo to pozd'e povjedźoł. Bo jo nad tym furt rozmyśloł! A vyśće mje ňepočuvali... No, a my muvili stopadesat, a joch mu dovała šance, tak viš co, tak napiš tam dvjeste... A stejňe to było gupje...

- A jo typnoł dvjesta osumdesat śtyry a ve finale to było dvjesta osumdesat šest, ňi? - A potem ešče było, kjela vína špaňelskeho vyprodukovały do ostatňich zemi za rok dva tisice šestnact, a jo muvim padesat... ja! že kolik tisíc... ňi, kolik miljonu hektolitru Špaňelsko za jedyn rok, a jo muvim: Špaňelsko? uňi tam ty vina enem tak rozdovajům, ňi?... - Hahaha, no, tam všeňdźe dajom, tam być bezdomovcem to muśi być luksus... Maš tu vino... (- Jadymy do Špaňelska na dovolenke... - Ćepło, vino...)

...tak muvim, dejmy padesat, napišće tam padesat... Ale ňi, to je moc, to je moc, napisali ôśymnost, było to śtyrycet, gdyby dali na mje, to by my vygrali.

- No a minule, ty vole, typek tam postavił grafickom kartym jakože z Lega, ňi, jakśi, kurva, Čiňan nebo co to był, a teraz była otazka, z kjela kostek to postavił... A Klara rachovała, ňi, že kostka muśi mjeć tela a tela... a tak to zrachovała, že třinact tísic, ňi?A že napiše to tam... A Pičak ňi, kurva, to je mało, to muśoł być tak miljon kostek miňimalňe, ňi... A všyscy dali potem na Pičaka, ty vole... Ve finale było třinact tisic dvjeste. My potem ubrali, že sedumset tisic, ale i tak...

W drugiej rozmowie brały udział dwie kobiety w wieku około 60-70 lat pochodzące z Bogumina:

Ale teraz mało ježdžům cugami. Všecko autym...

Jo se myślym, aňi to letišste ňyma využyte. Každyk přivjeźe, odvjeźe... Abo do Katovic, je to bližy.

Ňyma to využyte, no ... Tež juž ich ubrali, tych přimych vlakuv, do Bogumina vubec ňeježdžům, až z Ostravy muśi jechać. 
Ale jest. Ňi, ňi, ňi... jedům. Jedům.

Teraz byli naśi v Turecku. Młodźi. A odvožali ich autami ojcovje do Ostravy. Na Hlavňi.A dźeprym jechali na Mošnov. Tym cugym.

To možno, že ja. Bo jak jo była v Karvinej... v Ostravje, tak było pisane: Mošnov. Byli v Turecku?

$\checkmark$ Turecku byli, no.

U nas tež jedům do Turecka. Ale na tydźyň.

Ći tež ňebyli... śedym dňi. Ale pochvalovali se.

Ja? No už podrugje. Jedno to samy. Se jim tam podobo.

Potwierdza się w powyższych przykładach chaotyczny i niekonsekwentny dobór form i nieustanne przełączanie kodów. Z łatwością odnajdziemy wyrażenia i formy typowo śląskie, należące do tradycyjnego dialektu (kejśi, dźeprym, tela, joch mu dovała, jo pravim, jadymy), ale nawet charakterystyczne cechy fonetyczne, takie jak pochylone samogłoski czy labializacja o, pojawiają się niekonsekwentnie (sům - som, potym - potem, ôsmej - odvožali). Do kontaminacji form dochodzi nieraz nawet w obrębie jednego wyrazu - powtórzony kilkukrotnie przez jedną z rozmówczyń czasownikjedům (= jedou, pol.jadq) zaczyna się po czesku z przegłosem, a kończy po śląsku z rozłożoną nosówką i samogłoską pochyloną. Logika wypowiedzi, połączenia składniowe (aňi to letišťe), elementy służące funkcji fatycznej (tak jako spójnik wynikowy, jakože) - opierają się zdecydowanie na języku czeskim. Wulgarne przerywniki korespondują częściowo z polskim (kurva jako przecinek o słabszej sile rażenia), częściowo z czeskim (ty vole) uzusem językowym. Dominują czeskie połączenia frazeologiczne: ve finale, dali na mje, jo se bavił s, pochvalovali se, už podrugje. Całe czeskie wyrażenia, a nawet całe zdania są wkomponowywane w wypowiedzi z zachowaniem czeskiej fonetyki i czeskich form gramatycznych, nawet jeśli zawierają najbardziej podstawowe określenia, dla których nietrudno znaleźć formę właściwą dla dialektu. Przykładowo rodzina rozmówczyni była odwożona na Hlavňi, a nie na Głuvny dworzec w Ostrawie, a młodzi herczawianie, wspominając pytania w konkursie, w którym uczestniczyli, zadawane z całą pewnością po czesku, używają czeskich form liczebników (aby zaraz obok tego użyć śląskich: osumdesat, ale ôśymnost), wymieniają učitelkę (śl. rechtorka, pol. nauczycielka), a zamiast ňyskoro stało się coś pozdé (= pozdě, pol.późno). W tego typu „cytatach” z rzeczywistości czeskiej użytkownicy ponašymu są w stanie nawet użyć (choć bardzo niekonsekwentnie) iloczasu (kolik dỉlú = kolik dílů), pojawia się czeska odmiana ( $m i l j o n u$ hektolitru, = milionů hektolitrü) i fonetyka (natočila).

W innych (tu niecytowanych rozmowach) spotkałem się nawet z wybiórczym użyciem form obecnej češtiny, np. odchodzajům vocad'(cz. odsud, śl. stela, stůnd, pol. stąd). Cug, zadomowione 
na Śląsku stare niemieckie zapożyczenie, pojawia się równolegle do nowszego czeskiego vlaku (mowa o pociągu), a czeska forma zaimka kolik (= ile) używana jest na zmianę z oryginalnym śląskocieszyńskim kjela. Do charakterystycznych słowacyzmów w powyższych cytatach należy czasownik počuvać (= počúvat', cz. poslouchat, pol. słuchać) i rzeczownikowa forma dovolenka (pol. urlop) zamiast przymiotnikowego czeskiego dovolená. Sformułowanie všeňdźe dajom musiało zapewne powstać pod wpływem języka polskiego (śl. všyndy dovajům, cz. všude dávají).

Świetnym przykładem mieszania kodów w ramach ponašymu jest następująca wypowiedź:

A potem ešče było, kjela vína špaňelskeho vyprodukovały do ostatňich zemi za rok dva tisice šestnact, a jo muvim padesat... ja! že kolik tisíc... ňi, kolik miljonu hektolitru Špaňelsko za jedyn rok, a jo muvim: Špaňelsko? ůňi tam ty vina enem tak rozdovajům, ňi?

Zaczyna się w dialekcie (przy czym forma potem bez pochylonego e brzmi dość polsko), następnie przechodzi do języka czeskiego z $h$ zamiast $g$ i wyraźnie wymówioną długą samogłoską. Kolejny wyraz (vyprodukovały) jest internacjonalizmem fonetycznie przystosowanym do śląszczyzny, po nim znowu język czeski, dalej wyraz muvim, który ma tu odmianę dialektalną, ale jego użycie w tym kontekście może kojarzyć się ze standardowym językiem polskim (w gwarach śląskich najczęściej godům/pravjym/padům, po czesku řikám/povídám, po słowacku hovorím/povedám). Potem pojawia się śląskie ja w znaczeniu tak/ano, ponownie czeszczyzna, pomiędzy którą wpadła dialektalna wymowa jedyn z pochyleniem, a na końcu jeszcze raz śląski oraz pochodzące z gwar morawskich słówko enem (śl.jyno, cz.jenom, pol. tylko).

\section{Wnioski}

Zjawisko mówienia ponašymu występuje na całym obszarze pierwotnego zasięgu dialektu cieszyńskiego w granicach Republiki Czeskiej (tzn. bez pasa gwar laskich na zachód od rzeki Łucyny), przy czym w rejonie Karwiny i Bogumina procesy bohemizacyjne są współcześnie już silne zaawansowane, użycie języka mieszanego dotyczy raczej średniego i starszego pokolenia. Inaczej ma się sytuacja na południe od Czeskiego Cieszyna, gdzie ponašymu stało się swego rodzaju interdialektem, podstawowym kodem komunikacyjnym używanym przez wszystkie pokolenia i warstwy społeczne. Posługiwanie się tym kodem nie wiąże się z poczuciem tożsamości narodowej. Jego użytkownikami są zarówno osoby określające się jako Czesi, jak też deklarujące narodowość polską czy nazywające siebie wyłącznie 
Ślązakami, Góralami, Cieszyniakami albo „tustelokami” (tutejszymi). Zwraca uwagę, że młodzież ucząca się w szkołach z polskim językiem nauczania czy osoby uczęszczające na polskojęzyczne nabożeństwa, czytające polskojęzyczną prasę regionalną i angażujące się w wydarzenia organizowane przez Polski Związek Kulturalno-Oświatowy są niemal w całości użytkownikami ponašymu ${ }^{4}$ oraz mają większą kompetencję w zakresie tradycyjnego dialektu cieszyńskiego. Wśród uczniów i absolwentów szkół czeskich korzystających wyłącznie z czeskich mediów jest natomiast zdecydowanie większy odsetek osób posługujących się wyłącznie językiem czeskim, a ich wersja mowy ponašymu jest posunięta wyraźnie w kierunku standardu czeskiego kosztem form dialektalnych. Obserwacje te, oparte na własnych badaniach, zasadniczo zgadzają się z tezami zawartymi we wcześniejszych opracowaniach tematu (np. Bogoczová, 1993, 1998; Bogoczová \& Bortliczek, 2017; Greń, 2000).

Użytkownicy ponašymu uświadamiają sobie substandardowy, mieszany charakter swojego języka i jego "dziwność". Przytoczyć tu można ciekawą wymianę zdań na temat cieszyńskiej „komoleniny" (komolit = zniekształcać, przekręcać) w regionie pomiędzy tymi samymi kobietami z Bogumina, których rozmowę o pociągach na lotnisko wcześniej analizowaliśmy:

Tož ja už teraz ňevjem, ňeumim aňi česki, aňi ponašymu, aňi polski, bo ź dźeckami, a s chłopym, mynžym, tak ůn z Bohumina, tak česki... prakticki Pjetrovice sům na graňicach, sům Gurne Marklovice a Dolne Marklovice... Jo muviła Karoliňe, tak mi to vyjechało, jo ji prajm [= pravjym] „pujdymy do narpy". A ona mi praj [= pravi], "kaj to idymy”. A jo prajm, „tak to žodnymu ňemuv, bo by mi řekli, že babička je gupjo". Papirňictvi, ale dycki sme muvili "narpa". A mi to tak vyjechało, že "idymy do narpy", a ona "kaj to idymy".

To tak jak syncy, jak byli mali, to my šli z roboty a jo pravjym, že "sćiśće to radjo, bo to tu jak na ryngišpilach". Tež mi syncy muvjům: „A mami, a co to je?”

\footnotetext{
${ }^{4}$ W tym miejscu zwrócić należy uwagę na fakt, że język polski w czeskiej części Śląska Cieszyńskiego jest w znacznej mierze kodem sztucznym, ograniczonym do dwujęzycznych napisów i nazw ulic czy stacji kolejowych, lekcji w szkołach polskojęzycznych, prasy (miesięcznik "Zwrot" i wydawany dwa razy w tygodniu "Głos"), nabożeństw, okazjonalnych przemówień na wydarzeniach organizowanych przez PZKO. W praktyce pierwszym językiem „zaolziańskich” Polaków jest śląski dialekt cieszyński lub ponašymu. Już w latach 90 . XX wieku aż $67 \%$ uczniów polskich szkół średnich przyznawało się do trudności z porozumieniem na terenie Polski (Bogoczová, 1993, s. 41), a stosunek do polskości znacznej części spośród 30000 członków polskiej mniejszości narodowej ilustruje następująca wypowiedź młodego mieszkańca Dolnego Żukowa koło Czeskiego Cieszyna zanotowana przez Irenę Bogoczovą w 2013 r.: „Tu v tych Čechach bych potrafił cośi povjedźeć, a apropo Polski tam vogule ňimům pojyňća. My můmy tendencje jakśikej śe pokažde podźivać na ČT 2, TV NOVA, a v tej Polsce akurat vjym gdo je prezydent a tym to kůňčy, abych provde řek. Ňi že bych śe tej Polski jakśikej strůnił, ale jo je tu jakśi zaryty do tych Čech. Jo jako se považujym na přykład za Poloka, ale eśi bych se mjoł poruvnać fakt s Polokym, tak tego můmy doś mało, no, spulnego" (Bogoczová \& Bortliczek, 2017, s. 164). (pol. „Tu w tych Czechach bym potrafił coś powiedzieć a apropos Polski tam w ogóle nie mam pojęcia. My mamy tendencję jakoś zawsze popatrzeć na ČT 2, TV NOVA, a w tej Polsce to wiem, kto jest prezydentem i tyle, prawdę mówiąc. Nie że bym się tej Polski jakoś wstydził, ale ja tu jestem jakoś zaryty do tych Czech. Ja tam się uważam na przykład za Polaka, ale jak bym się miał porównać serio z Polakiem, to mamy dość mało, no, wspólnego.")
} 
No, no, to same, to same. Všecko.... „Rožňi”, a mami mi praje: „rozsvit', ne rožňi”. No tak... Momy česki škoły.

No, hlavňe! A tyn staršy synek, tyn dycki pravi mojimu: „řekňi mamce, at' mluvi ňemecki". Bo jo s mojimi rod'ičami ponašymu, ale s ňim už po česku, vjyšs, takže to było... komonolina (= komolenina)...

Mama muviła ňemjecki, jak co před nami, jak sme se zešli na kava ${ }^{5}$, aby cośik...

Abyśće ňerozumjeli.

No, a tak ynym ňemjecki. A teroz tego lutuje...

My juž teraz můmy komolůňine fakt: ňemecki, česki, polski, i ruski se mi přimješo do tego...

Všecko dogrůmady, ty mjana, bo to ňima aňi česki, aňi... no všelijaki.

Niezależnie od tego zwłaszcza w południowej części regionu ponašymu cieszy się wśród użytkowników znacznym prestiżem jako wyraz lokalnej specyfiki pogranicznego regionu. Odgranicza ono wyraźnie Śląsk Cieszyński od reszty kraju, jest to w końcu współcześnie jedyny skrawek Republiki Czeskiej, gdzie w zwarty sposób funkcjonuje język inny niż czeski. Jednocześnie często służy jako łącznik w komunikacji pomiędzy wszystkimi narodami pogranicza zarówno rdzennymi Ślązakami, jak i przybyszami z Czech i Moraw, Polski oraz Słowacji. Jak długo jeszcze będzie żywe, zanim zleje się z językiem czeskim, pozostawiając po sobie najwyżej akcent i trochę regionalizmów (jak to się stało z sąsiednimi gwarami laskimi, które w codziennej komunikacji praktycznie zanikły, pozostawiając po sobie "ostravštinę" - charakterystyczne brzmienie miejscowej czeszczyzny, czy też z dialektem cieszyńskim na terenie Polski, który w praktyce przekształcił się w regionalnie zabarwioną polszczyznę)? Tendencja w tym kierunku jest ewidentna. W obrębie ponašymu przejmowane jest coraz więcej leksyki czeskiej (nie ma ona już żadnej konkurencji w zakresie nazywania zjawisk współczesnego świata). Ponadto - i tu oddajmy głos 53-letniej mieszkance Herczawy: „My ešče s tymi dźeckami muvili tak ponašymu, ale teraz juž te młode maminki, co tu sům, to se snažům už s tymi małymi d’etmi... už jako muvjům po česku"." Bez wątpienia jednak jeszcze przez co najmniej kilka dekad czeska część Śląska Cieszyńskiego będzie się wyróżniać socjolingwistyczną specyfiką.

\footnotetext{
${ }^{5}$ Warto w tym miejscu zwrócić uwagę na hybrydę gramatyczną: koniugację zgodnie ze standardem czeskim (jsme se...) i deklinację według wzorca śląskiego, i to ze Śląska centralnego, który w tym zakresie obejmuje tradycyjnie również Bogumin z przyległościami (na kava).

${ }^{6}$ "My jeszcze z tymi dziećmi mówiliśmy tak ponaszymu, ale teraz już te młode matki, co tu są, to się starają już z tymi małymi dziećmi... no już mówią po czesku."
} 


\section{Bibliografia}

Bakala, J. (1992). Śląsk Cieszyński w średniowieczu (do roku 1450). W M. Borák \& D. Gawrecki (Red.), Zarys dziejów Śląska Cieszyńskiego (ss. 17-30). Ostrawa: Advertis.

Bogoczová, I. (1993). Jazyková komunikace mládeže na dvojjazyčném území českého Těšínska. Ostrava: Sfinga.

Bogoczová, I. (1998). Świadomość i kompetencja językowa najmłodszej generacji Polaków na Zaolziu. Ostrava: Ostravská univerzita, Filozofická fakulta.

Bogoczová, I., \& Bortliczek, M. (2017). Jazyk príhraničního mikrosvěta (běžná mluva Těšíňanů v ČR): Język przygranicznego mikroświata (mowa potoczna mieszkańców Zaolzia). Ostrava: Ostravská univerzita.

Bogus, M. (2012). Nauczyciele szkół ludowych Śląska Cieszyńskiego w XIX i na początku XX wieku: Uwarunkowania prawne i zawodowe. Częstochowa: Akademia Jana Długosza.

Fałowski, A. (2011). Język ukraiński. W B. Oczkowa, E. Szczepańska \& T. Kwoka (Red.), Słowiańskie języki literackie: Rys historyczny (ss. 127-144). Kraków: Wydawnictwo Uniwersytetu Jagiellońskiego. Gawrecki, D. (2017). Jazyk a národnost ve sčítáních lidu na Těšínsku v letech 1880-1930. Český Těšín: Muzeum Těšínska.

Gąsior, G. (2008). Zaolzie. W A. Knyt (Red.), Zaolzie: Polsko-czeski spór o Śląsk Cieszyński 1918-2008 (ss. 2-3). Warszawa: Fundacja Ośrodka Karta, Dom Spotkań z Historią.

Greń, Z. (2000). Śląsk Cieszyński: Dziedzictwo językowe. Warszawa: Slawistyczny Ośrodek Wydawniczy.

Hannan, K. (1996). Borders of language and identity in Teschen Silesia. New York, NY: Peter Lang Publishers.

Kadłubiec, K. D. (Red.). (1997). Polská národnostní menšina na Těšínsku v České republice. Ostrava: Filozofická fakulta Ostravské univerzity.

Kasza, K. (2009). Sytuacja polityczna i narodowościowa w Austro-Węgrzech w latach 1848-1918. Pobrano 21 października 2019, z https://historia.org.pl/2009/09/03/sytuacja-polityczna-i -narodowosciowa-w-austro-wegrzech-w-latach-1848-1918/

Knop, A. (1965). Spisovná čeština ve Slezsku v 16. století. Praha: Státní pedagogické nakladatelství. Poloczkowa, B. (2003). Archiwalia cieszyńskie jako źródło do badań historii języków urzędowych na Śląsku Cieszyńskim. Pamiętnik Cieszyński, 18(1), 35-44.

Raclavská, J. (1998). Język polski na Śląsku Cieszyńskim w XIX wieku. Ostrava: Filozofická fakulta Ostravské univerzity.

Šefčík, E. (2001). Zemské zřizení Těšínského knížectví z konce 16. století: Studie o Těšínsku 17. Český Těšín: Muzeum Těšínska.

Spyra, J. (2006). Dlo pamięci rodu ludzkiego: Z wprowadzeniem i komentarzem Janusza Spyry. Cieszyn: Muzeum Śląska Cieszyńskiego.

Staatsgrundgesetz vom 21. December 1867, über die allgemeinen Rechte der Staatsbürger für die im Reichsrathe vertretenen Königreiche und Länder. (b.d.). Pobrano 21 października 2019, z https://www.ris.bka.gv.at/GeltendeFassung.wxe?Abfrage=Bundesnormen\&Gesetzesnum mer $=10000006$ 
Wandruszka, A. \& Urbanitsch, P. (2003). Die Habsburgermonarchie 1848-1918: T. 3. Die Völker des Reiches. Wien: VÖAW.

\section{Ponašymu - the mixed language code of Těšín Silesia}

\section{Abstract}

This article describes the development of the linguistic situation in the border region of Těśn Silesia throughout its history, with particular emphasis on the so-called ponašymu - a mixed language code used in the Czech part of the region. It is based on a random combination of forms of the traditional Těšín dialect with the standard Czech language and, to a lesser extent, elements borrowed from the Polish and Slovak languages and from neighbouring Moravian dialects. An important element of the study is the analysis of selected material collected by the author during fieldwork in August 2018.

\section{Keywords:}

Silesian ethnolect; Czech language; Polish language; mixed languages; ponašymu; code-switching; Těšín Silesia; Zaolzie region

\section{Ponašymu - mieszany kod językowy czeskiego Śląska Cieszyńskiego}

Artykuł opisuje rozwój sytuacji językowej w pogranicznym regionie Śląska Cieszyńskiego na przestrzeni dziejów, ze szczególnym uwzględnieniem tzw. ponašymu - mieszanego kodu językowego używanego w czeskiej części regionu. Oparty jest on na dowolnym łączeniu form tradycyjnego śląskiego dialektu cieszyńskiego ze standardowym językiem czeskim i w mniejszym stopniu elementami zapożyczonymi z języka polskiego, słowackiego i sąsiednich gwar morawskich. Ważnym elementem pracy jest analiza wybranych materiałów zebranych przeze mnie w trakcie badań terenowych w sierpniu $2018 \mathrm{r}$.

\section{Słowa kluczowe:}

etnolekt śląski; język czeski; język polski; języki mieszane; ponašymu; przełączanie kodów; Śląsk Cieszyński; Zaolzie

\section{Citation:}

Czaiński, K. (2019). Ponašymu - mieszany kod językowy czeskiego Śląska Cieszyńskiego. Adeptus, 2019(14). https://doi.org/10.11649/a.1974 